\title{
PRODUCTION AND OPTIMIZATION OF LIPASE FROM CANDIDA RUGOSA USING GROUNDNUT OILCAKE UNDER SOLID STATE FERMENTATION
}

\author{
K. S. S. Rekha ${ }^{1}$, Dr. M. V. V Chandana Lakshmi ${ }^{2}$, Dr. V. Sri Devi ${ }^{3}$ M.siddartha Kumar $^{4}$ \\ ${ }^{1,4}$ M.tech, ${ }^{2,3}$ Associate Professor, Centre for Biotechnology, Department of Chemical Engineering, Andhra University, \\ Visakhapatnam-03, Andhra Pradesh, India, \\ kolli.rekha@gmail.com,mahantilakshmi@yahoo.com.vellurusridevi@yahoo.co.in,siddharthakumar.m@gmail.com
}

\begin{abstract}
The present work deals with the screening of microorganisms Candida rugosa NCIM 3467 and Penicillum citrinum NCIM 765 with different agro residues - rice bran, wheat bran, groundnut oil cake, coconut oil cake and sesame oil cake for maximum production of lipase. Among all the industrial residues, Groundnut oil cake supported the maximum lipase production by C.rugosa NCIM 3467. The physical factors such as fermentation time, temperature, $p H$, inoculum age, inoculum level, initial moisture content played a vital role in lipase production and further the yield was improved with the supplementation of carbon and organic nitrogen sources to the solid medium. At 5 days of fermentation, $32{ }^{\circ} \mathrm{C}, \mathrm{pH} 6,5$ day old culture, $15 \%$ inoculum level and at $60 \%$ initial moisture content, lipase activity of $57.25 \mathrm{U} / \mathrm{ml}$ was obtained. Further the activity was raised to $63.35 \mathrm{U} / \mathrm{ml}$ by supplementing the substrate media with maltose $(5 \% w / w)$ and peptone $(3 \% w / w)$.
\end{abstract}

Keywords: Candida rugosa, Pencillum citrinum, Solid state Fermentations, Lipase, Optimization and Characterization. $* * * * * *$

\section{INTRODUCTION}

Lipases (triacylglycerol acylhydrolases, E.C.3.1.1.3) catalyze the hydrolysis of triglycerides to glycerol and free fatty acids at an oil - water interface [15],16]. Lipases can also perform the reverse reaction of synthesis of triacylglycerols from free fatty acids and glycerols [3], [6]. This property is extensively used in trans- and inter-esterification reactions in organic solvents to produce useful acylglycerols. Each application requires unique properties with respect to specificity, stability, temperature and $\mathrm{pH}$ dependence or ability to catalyze synthetic ester reactions in organic solvents.

Interest in lipases has increased markedly in the last two decades owing to their applications in oleochemical, detergent, organic industries, leather industry, environmental management, cosmetics and perfume industry, biomedical and biosensors [9], [12], [2], and [17]. Lipases of microbial origin have gained considerable attention in the field of biotechnology and a large number of microbial strains have been used for the enzyme production. Lipase production was studied by Candida rugosa in universal yeast medium [7].Lipases are produced by several microorganisms, namely bacteria, fungi, archea, eucarya as well by animals and plants. Commercially useful lipases are usually obtained from microorganisms that produce a wide variety of extracellular lipases [2]. Microbial commercial lipases are mainly produced from Pseudomonas [19], Mucor[1], Geothrium [31], Rhizopus [13], P.chrysogenum [3], Bacillus subtilis [3], Aspergillus oryzae [3], P. roqueforti [3] and Candida sp.[28],[5],[11] such as C. rugosa [3], C. Antarctica [3] and C. parapsilosis [3]. Production of lipase can be significantly increased by the careful selection of the nitrogen and carbon sources for microbial growth and the optimization of the composition of the growth medium [28],[5],[8] Most importantly, since lipase is an inducible extracellular enzyme, by application of a proper inducer the lipase production can be considerably increased[21]. Histo-chemical study conformed that lipase activity is exclusively associated to oil-bodies [20]. In recent years, increasing attention has been paid to the conversion of processing industry wastes by microbial lipases or their use as biosensors [27], [31].

\section{MATERIALS AND METHODS}

\subsection{Microorganism}

C.rugosa NCIM 3467 and Pencillium citrinum NCIM 765 was purchased from the National Collection of Industrial Microorganisms (NCIM) Pune, C.rogusa in yeast medium (YM) and P.citrinum in potato dextrose agar medium (PDA) maintained at $4{ }^{\circ} \mathrm{C}$ and sub cultured once a month[5]. 


\subsection{LIPASE PRODUCTION BY SSF}

$5 \mathrm{~g}$ substrate was taken in a $250 \mathrm{ml}$ Erlenmeyer flask and then moistened with $5 \mathrm{ml}$ of salt solution and sterilized at $121^{\circ} \mathrm{C}$ for $30 \mathrm{~min}$. The fermentation process was started by adding $1 \mathrm{ml}$ of spore suspension containing 107 spores $/ \mathrm{mL}$ from a 7-dayold culture grown on medium. The whole content was mixed thoroughly and then incubated at $30^{\circ} \mathrm{C}$ for 7 days.

\subsection{SCREENING OF SUBSTRATE}

Substrates such as rice bran (RB), groundnut oil cake (GOC), sesame oil cake (SOC), coconut oil cake (COC) and wheat bran (WB) were purchased from the local market, Visakhapatnam are used for lipase production. Microorganisms were grown under solid state fermentation and conditions were optimized for the maximum production of lipase. The production of enzyme was carried out considering different parameters like selection of substrate, incubation period, temperature, initial $\mathrm{pH}$, inoculum age, inoculum level, initial moisture levels and various carbon and nitrogen additives etc.

\subsection{EFFECT OF PHYSICAL PARAMETERS}

\subsubsection{Effect of Incubation time on lipase activity}

The effect of incubation time on lipase activity was carried at various time periods such as $24,48,72,96,120,144$ and 168 hours in medium and incubated at $30^{\circ} \mathrm{C}$. The fermentation time was kept as constant for the consecutive experiments.

\subsubsection{Effect of Incubation temperature on lipase activity}

For selection of optimum temperature for the production of lipase the temperatures varying from $28-48^{\circ} \mathrm{C}$ were selected and fermentation was carried for 7 days

\subsubsection{Effect of $\mathrm{pH}$ on lipase activity}

To study the effect of $\mathrm{pH}$, the lipase activity was measured at various $\mathrm{pH}$ ranging from 3 to 8 . The $\mathrm{pH}$ was varied using different buffers (citrate buffer for $\mathrm{pH}$ 3-6.phosphate buffer for $\mathrm{pH}$ 7-8 and borate buffer for $\mathrm{pH} 9-10$ ).

\subsubsection{Effect of inoculum age on lipase activity}

The effect of inoculum age on lipase production was carried out using 1 to 8-day old day culture.

\section{3.5 Effect of inoculum level on lipase activity}

The effect of inoculum level on lipase production was carried out by fermentation of different inoculum levels ranging from $5-25 \%(\mathrm{v} / \mathrm{w})$.

\subsubsection{Effect of initial moisture content on lipase activity}

To investigate the influence of the initial total moisture content (before autoclaving) of the substrate, the fermentation was carried out under various initial moisture contents $40-90 \%$ of substrate, which was adjusted with distilled water.

\subsection{EFFECT OF CHEMICAL PARAMETERS}

\subsubsection{Effect of Carbon supplements on lipase activity}

Substrate is supplemented with different carbon supplements like maltose, lactose, sucrose and fructose at a final concentration $5 \%(\mathrm{w} / \mathrm{w})$.

\subsubsection{Effect of Nitrogen supplements on lipase activity}

Substrate is supplemented with different nitrogen supplements such as yeast extract, beef extract, peptone and urea at a concentration of $3 \%(\mathrm{w} / \mathrm{w})$ were used.

\subsection{EXTRACTION OF CRUDE ENZYME}

$100 \mathrm{ml}$ of distilled water was added to each flask and the mixture was shaken for $30 \mathrm{~min}$ at room temperature to facilitate the extraction of the enzymes from fermented medium. At the end of the extraction the suspension was squeezed through a double-layered muslin cloth and it was centrifuged at $12,000 \mathrm{rpm}$ for $5 \mathrm{~min}$. The clear supernatant obtained was used as the extracellular enzyme.

\subsection{LIPASE ASSAY (Titrimetric method)}

Lipase activity was assayed by titrimetric method. In this method, $1.25 \mathrm{ml}$ of olive oil and $4 \mathrm{ml}$ of $0.1 \mathrm{M}$ phosphate buffer and the fermented filtrate is added $1 \mathrm{ml}$ in a $250 \mathrm{ml}$ flask and immediately incubated at $37^{\circ} \mathrm{C}$ for $20 \mathrm{~min}$ at $60 \mathrm{rpm}$. Later the reaction was inhibited by addition of chloroform: ethanol mixture in the ratio of $2: 1$. The fatty acids liberated during the incubation were titrated against $0.05 \mathrm{~N} \mathrm{NaOH}$ and the pink color indicates the end point.

One unit of lipase is defined as the amount of enzyme that liberates one micromole of fatty acid per minute under the assay conditions [9].

\section{RESULTS AND DISCUSSION}

The present study deals with the production of lipase from candida rugosa NCIM 3467 using groundnut oil cake under solid state fermentation. The results are presented and discussed in light and existing literatures. Process parameters like fermentation time, temperature, $\mathrm{pH}$, inoculum age, inoculum level and initial moisture content were optimized. The basal medium was supplemented with carbon and organic nitrogen. 


\subsection{SUBSTRATE SCREENING}

The selection of ideal agro-industrial residues for the enzyme production in a SSF process depends upon several factors, mainly with cost and availability of the substrate material. Five different substrates groundnut oil cake, rice bran, wheat bran, sesame oilcake and coconut oil cake were screened for the maximum production of lipase. Maximum enzyme production was obtained with groundnut oil cake.

\subsection{SCREENING OF MICROORGANISMS}

C.rugosa NCIM 3467 and P.citrinum NCIM 765 were screened for production of lipase under SSF. C.rugosa NCIM 3467 produced relatively more production of lipase on groundnut oil cake substrate with $42.50 \mathrm{U} / \mathrm{ml}$ of enzyme activity (Chart 4.1). C.rugosa was selected to optimize the process parameters for the enzyme production on groundnut oil cake substrate under the SSF.

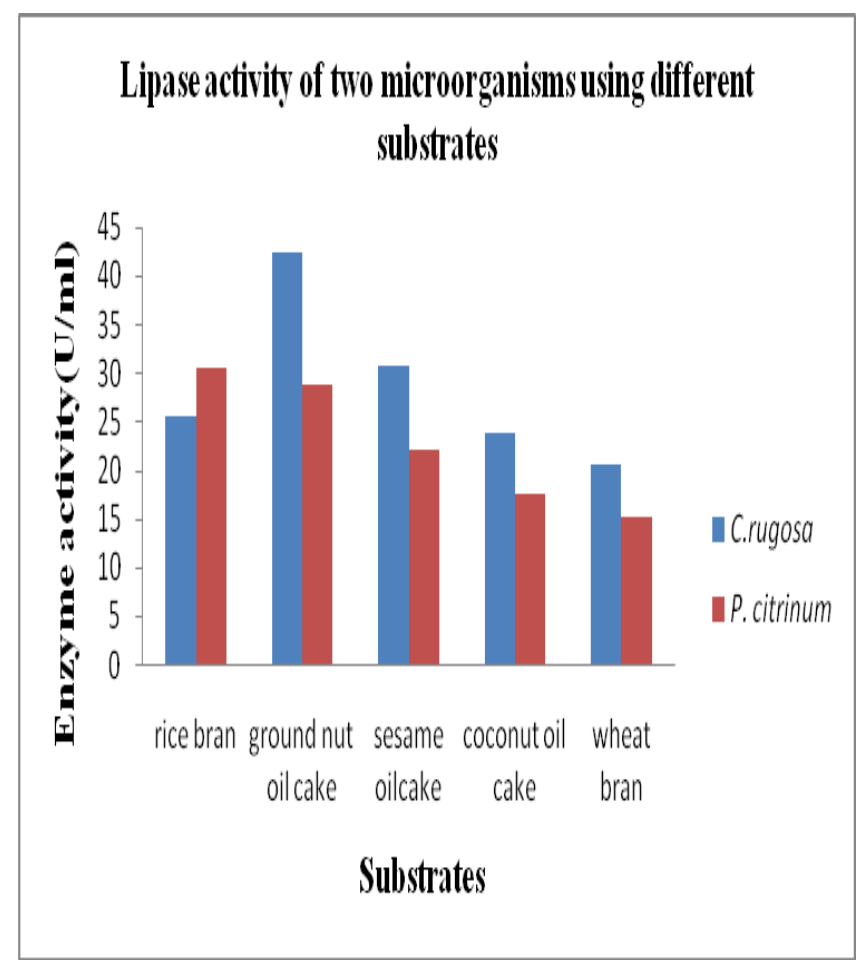

Chart 4.1 Lipase activity of two microorganisms using different substrates

\subsection{OPTIMIZATION OF PROCESS PARAMETERS FOR LIPASE PRODUCTION}

Any fermentation process is governed by a large number of physical, chemical and biological factors. The protocol adopted for the optimization of process parameters was to evaluate the effect of individual parameters at a time and to incorporate it at the standard level.

\subsubsection{Effect of physical parameters}

\subsubsection{Effect of fermentation time on lipase activity}

The production of lipase was studied by conducting the fermentation using C.rugosa NCIM 3467 for different time intervals (1, 2, 3, 4, 5, 6 and 7 days). The enzyme production was increased with increasing time and maximum enzyme activity $48.50 \mathrm{U} / \mathrm{ml}$ was obtained after 5 days of incubation (Chart 4.2).

Jigita Padhiar [14] reported that lipase production has also been influenced by the time course of the fermentation process. The highest yield of lipase was recorded after 5 days for Pseudomonas aeruginosa.

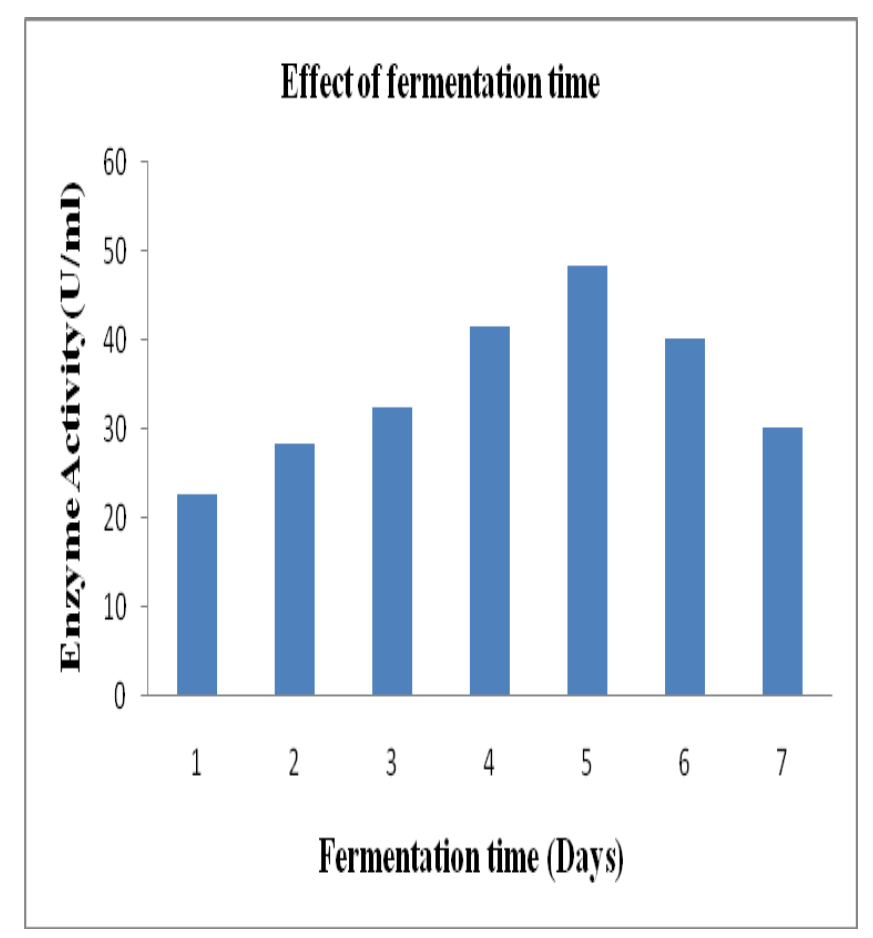

Chart 4.2 Effect of fermentation time on Lipase activity

\subsubsection{Effect of temperature on lipase activity}

The inoculated flasks were incubated at different temperatures to determine the optimum fermentation temperature for lipase production. The enzyme production was carried out by C.rugosa NCIM 3467 at $28-48^{\circ} \mathrm{C}$ temperature range. The optimum incubation temperature of the production of lipase $50.25 \mathrm{U} / \mathrm{ml}$ was found at $32^{\circ} \mathrm{C}$ (Chart 4.3). Enzyme production was reduced when the incubation temperature was increased above $32^{\circ} \mathrm{C}$.

Thowlath Noora Parveen [30] reported that the lipase production was increased at $\mathrm{pH} 5,32^{\circ} \mathrm{C}$, using Aspergillus flavus. 


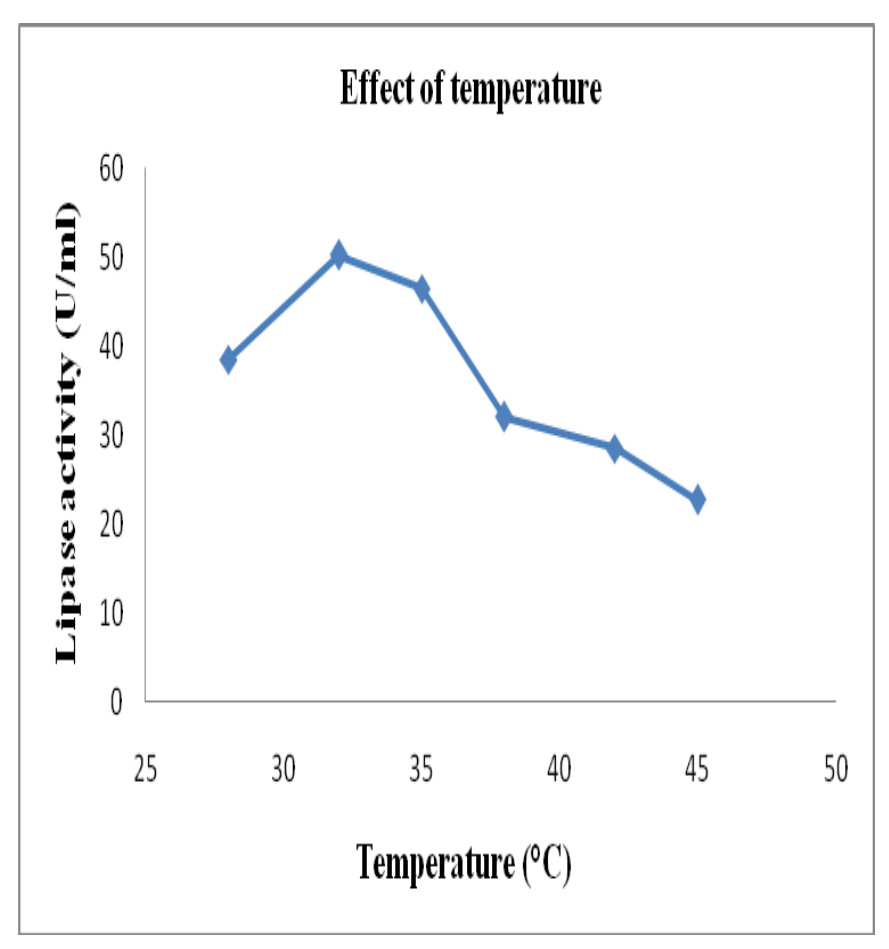

Chart 4.3 Effect of temperature on lipase activity.

\subsubsection{Effect of $\mathrm{pH}$ on lipase activity}

The effect of $\mathrm{pH}$ can be measured by fixing the process variables incubation period for 5 days and the temperature at $32^{\circ} \mathrm{C}$, the optimum values obtained from the previous steps. The amount of lipase produced is measured at each $\mathrm{pH} 4-9$. The maximum lipase activity of $51.25 \mathrm{U} / \mathrm{ml}$ is observed at $\mathrm{pH}$ 6.0 (Chart 4.4). Enzyme production was decreased when increased above $\mathrm{pH} 6$. As the metabolic activities of the microorganisms are very sensitive to changes in $\mathrm{pH}$ and is found to be affected if $\mathrm{pH}$ level is higher or lower compared to the optimum value.

Falony [10] reported that the optimum lipase activity was obtained at $\mathrm{pH}$ 6, by using Aspergillus niger.

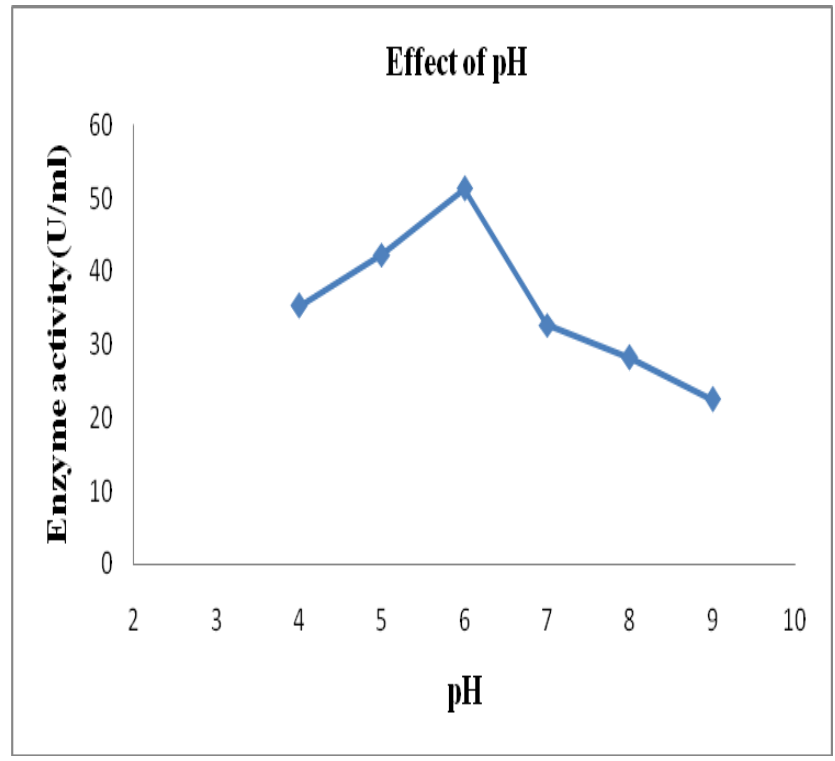

Chart 4.4 Effect of $\mathrm{pH}$ on lipase activity.

\subsubsection{Effect of inoculum age on lipase activity}

The effect of inoculum age on lipase production was studied by conducting the fermentation with different inoculum age. The substrate was inoculated with 1 to 8 -day old day culture. The five day old culture gave maximum production of lipase $53.28 \mathrm{U} / \mathrm{ml}($ Chart 4.5).

Sarada Sarkar [25] results showed that the lipase activity was maximum in the 3 days old culture.

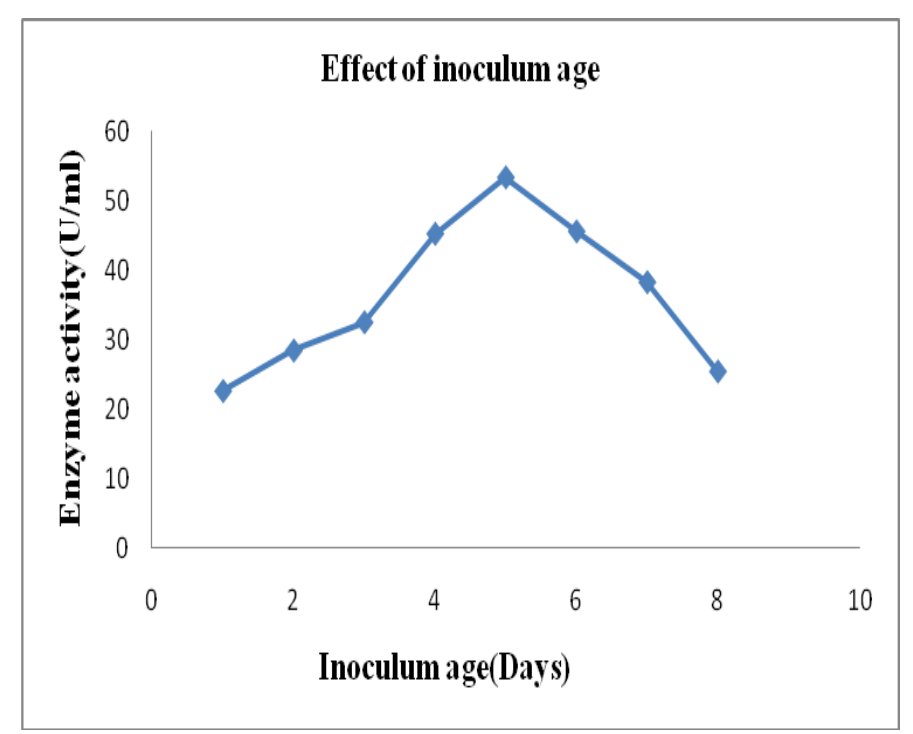

Chart 4.5 Effect of inoculum age on lipase activity. 


\subsubsection{Effect of inoculum level on lipase activity}

The effect of inoculum level on lipase production was studied by conducting the fermentation with different inoculum levels. Various inoculum levels $(5-25 \%)$ were tried to study their effect on enzyme production. The higher enzyme production $56.25 \mathrm{U} / \mathrm{ml}$ (Chart 4.6) was obtained at $15 \%$ (v/w). High inoculum levels are inhibitory in nature. Inoculum level as compared to low or high inoculum levels while lower inoculum levels require more time for fermenting the substrates in SSF [4].

Tehreema iftikar [29] reported that the highest lipase activity was found at $1.0 \mathrm{ml}$ of inoculums size by using Rhizopus oligosporousuv -31

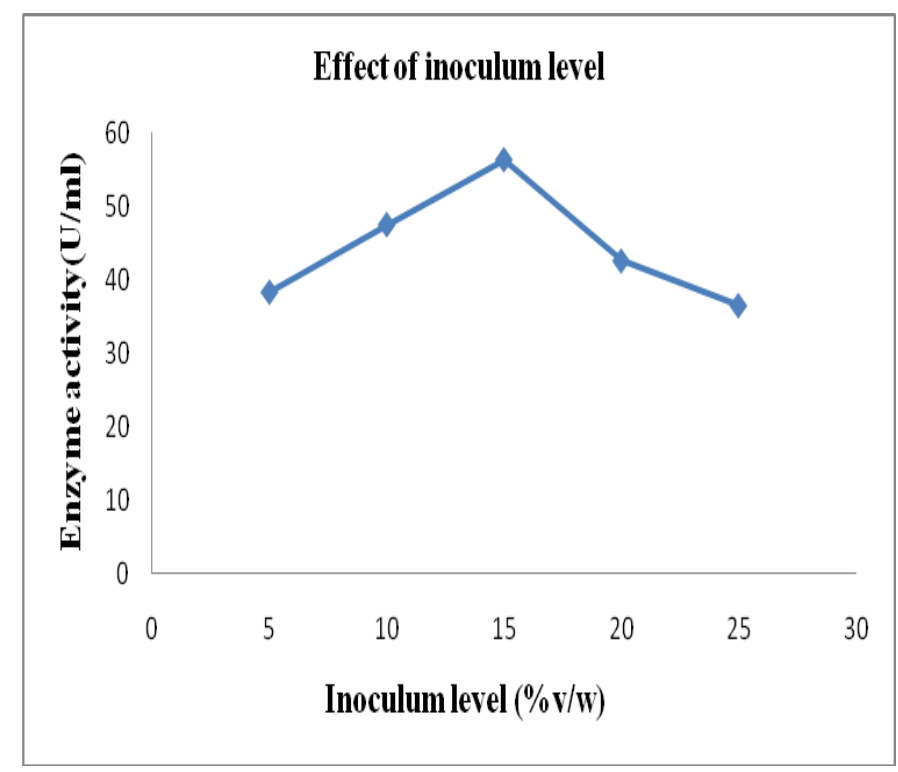

Chart 4.6 Effect of inoculum level on lipase activity.

\subsubsection{Effect of initial moisture content on lipase activity}

The optimum initial moisture content for lipase production was determined by adjusting the initial moisture content of the fermentation substrate to varying levels of 40-90\%. A moisture level of $60 \%(\mathrm{v} / \mathrm{w})$ was found to be optimum for lipase production $57.25 \mathrm{U} / \mathrm{ml}$ (Chart 4.7).

Saima Rehman [24] reported that the maximum lipase activity was observed at $60 \%$ initial moisture content,using Penicillium notatum.

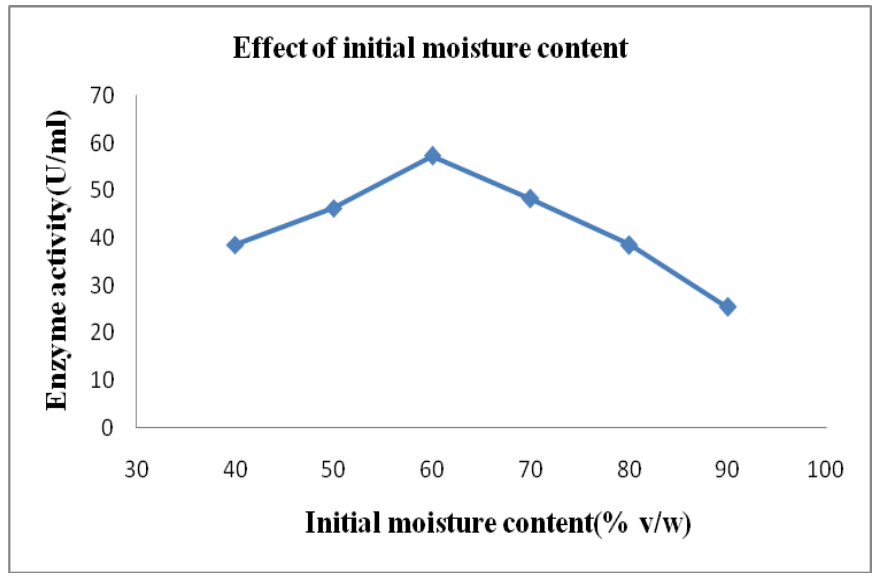

Chart 4.7 Effect of initial moisture content on Lipase activity.

\subsubsection{Chemical parameters}

\subsubsection{Effect of carbon supplements on lipase activity}

Influence of various carbon supplements on enzyme production was studied by adding various supplements namely maltose, lactose, sucrose and fructose $5 \%(\mathrm{w} / \mathrm{w})$ to fermentation medium. Of the four different carbon supplements used as enrichment, maltose was a good carbon supplement which gave maximum lipase activity $60.25 \mathrm{U} / \mathrm{ml}$ (Chart 4.8).

Saima Rehman [24] reported that the presence of $2 \%$ maltose resulted in the highest lipase yield of $4626 \mathrm{U} / \mathrm{gds}$ using Penicillium notatum. Rao [23] and Mahanta [18] reported that the presence of maltose in the growth media enhanced the lipase production by Pseudomonas aeruginosa and Candida rugosa respectively.

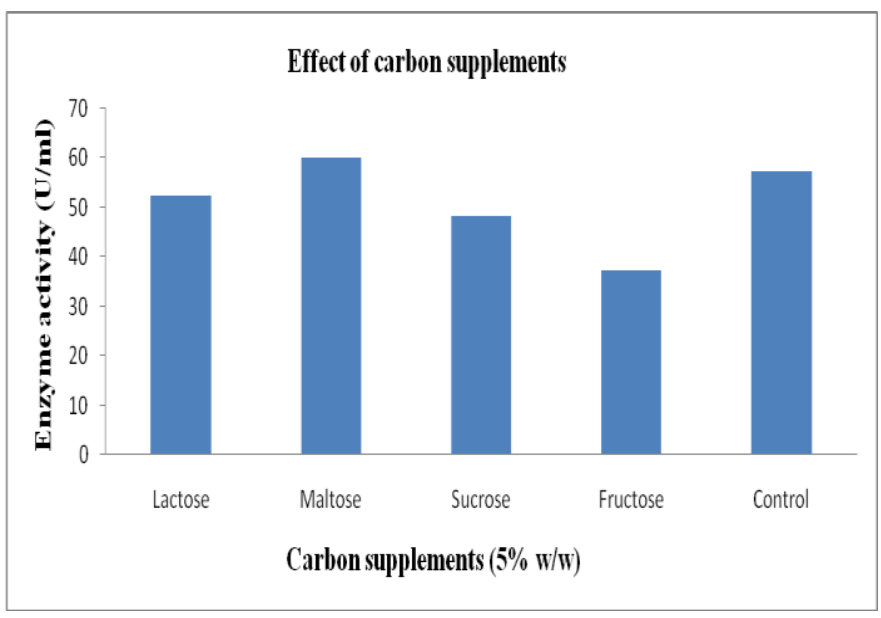

Chart 4.8 Effect of different carbon supplements on lipase activity. 


\subsubsection{Effect of nitrogen supplements on lipase activity}

Influence of organic nitrogen supplements on enzyme production was studied by adding various supplements namely yeast extract, peptone, beef extract and urea $3 \%(\mathrm{w} / \mathrm{w})$ to fermentation media. Of the four different nitrogen supplements used as enrichment, it was observed peptone a good nitrogen supplement which gave maximum lipase production $63.35 \mathrm{U} / \mathrm{ml}$ (Chart 4.9).

Shu yang sun [26] reported that the supplementation of $2 \%$ $(\mathrm{w} / \mathrm{w})$ of peptone gave the highest activity of $16.855 \mathrm{U} / \mathrm{kg}$ using Rhizopus chinensis. Peptone was also found to efficiently improve the production of extracellular lipase.

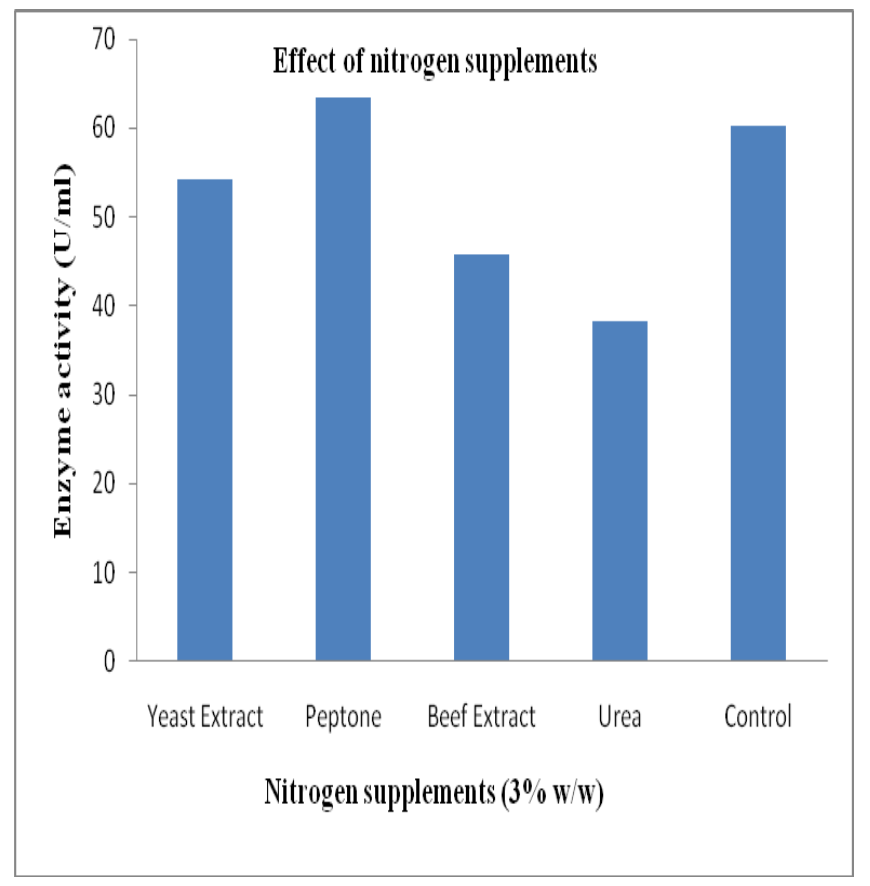

Chart 4.9 Effect of nitrogen supplements on lipase activity

\section{SUMMARY AND CONCLUSION}

Lipases have found a wide range of applications in various industries such as chemical industry, food industry, textile, leather and pulp industries, synthetic chemistry and detergents etc. SSF has revealed the possibilities of effective utilization of agro-industrial residues for value addition through biotechnological means, lipase production by SSF using agroindustrial residues brings down the cost of production and it also provide an alternative path for the effective utilization of such nutrients rich agro-industrial residues.

Fermentation time of 5 days, temperature of $32^{\circ} \mathrm{C}$, $\mathrm{pH} 6.0,5$ th day old culture, $15 \%$ inoculum level and $60 \%$ initial moisture content were found to be the optimum conditions for lipase production and the maximum lipase activity was found to be $57.25 \mathrm{U} / \mathrm{ml}$. Different carbon and nitrogen sources were used as supplements at $5 \%(\mathrm{w} / \mathrm{w})$ and $3 \%(\mathrm{w} / \mathrm{w})$ respectively, to determine their effect on enzyme yield. Maltose $(60.25 \mathrm{U} / \mathrm{ml})$ and Peptone $(63.35 \mathrm{U} / \mathrm{ml})$ supplements improved enzyme activity.

The present study indicates that groundnut oil cake is potential substrate for lipase production using C.rugosa NCIM 3467 under SSF. Results obtained with study are comparable hence process can be exploited for commercial application after a comprehensive study.

\section{REFERENCES}

[1] Abbas H, Hiol A, Deyris V, Comeau L., Isolation and extraction of an isocellular lipase from Mucor sp strain isolated from palm fruit, Enzyme Microb. Technol., 31 ,968-975 (2002)

[2] Akimoto M, Nagashima Y and Sato D., A kinetic study on lipase-catalyzed interesterification of soyabean oil with oleic acid in a continuous packed bed reactor, Appl Biochem Biotechnol., 81,131-142 (1999)

[3] Aravindan R, Anbumathi P and Viruthagiri T., Lipase applications in food industry, Ind. J. of Biotechnol., Vol 6, 141-158 (2007)

[4] Asgher M., Asad M.J. and Legge R.L., Enhanced lignin peroxidase synthesis by Phanerichaete chrysosporium in solid state bioprocessing of a lignocellulosic substrate, World J. Microbiol. Biotechnol., 22, 449453 (2006).

[5] Benjamin S and Pandey., Optimization of liquid media for lipase production by Candida rugosa.,

[6] Bezbradica D, Mijin D, Siler-Marinkovic S, Knezevic Z, Mol J., A kinetic study of Candida rugosa from lipase catalyzed synthesis of amyl isoburyrate in organic solvent and solvent -free system, J. Mol. Catal.B. Enzyme, 38,11-16 (2006) Biores. Technol., 55, 167-170 (1996)

[7] Ciafardini G, Zullo B.A and Iride A., Lipase production by yeasts from extra virgin olive oil, J. of food Microb. 23., 60-67 (2006).

[8] Dalmau E, Montesinos J. L, Lotti M and Casas C., Effects of different carbon sources on lipase production by Candida rugosa, Enzy. Microbial. Tech., 26,657-663 (2000)

[9] Freire D.M, Teles E.M.F, Bon E.P.S and Lippel San't Anna G., Lipase production by Penicillum restrictum in a bench-scale fermentor: Effect of carbon and nitrogen nutrition, agitation and aeration, Appl Biochem Biotechnol ., 63-65, 409-421 (1997).

[10] Falony G., Janny Coca Armas, Julio C. Dustet Mendoza and Jose L. Martínez Hernández Production of extracellular lipase from Aspergillus niger by SolidState Fermentation, Food Technol. Biotechnol. 44, 235240 (2006). 
[11] Gordillo M.A, Montesinos L, Casas C., Improving lipase production from Candida rugosa by a biochemical engineering approach, Chem. phys. lipids., 93,131-142 (1998)

[12] Saxena RK, Gupta R, Yadav RP, Sheba Davidson W., Parametric optimization of Aspergillus terreus lipase production and its potential in ester synthesis, Process Biochem., 35,459-64 (2000)

[13] Hiol A, Jonzo M.D, Rugani N, Druet D, Sarda L, Comeau., Purification and characterization of an extracelular lipase from a thermophillic Rhizopus oryzae strain isolated from palm fruit., Enzyme Microb.Technol., 26,421-430 (2000).

[14] Jigita J Padhiar, Arijit A Das and Sourav S Bhattacharya, Optimization of process parameters influencing the submerged fermentation of extracellular lipases from Pseudomonas aeruginosa, candida albicans and Aspergillus flavus, Pak. J. Biol. Sci. 14, 10118 (2011).

[15] Kamini N.R, Fuijii T, Kurosu T, Lefuji H., Production, purification and characterization of an extracellular lipase from the yeast Cryptococcus sp. S-2, Process Biochem., 36,317-324 (2000)

[16] Knezevic Z, Siler-Marinkovic S, Mojovic L., Lipase immobilization in a hollow fiber membrane reactor: kinetic characterization and application for palm oil hydrolysis, Appl. Microbiol. Biotechnol., 49,267-271 (1998)

[17] Macrae AR, Hammond RC., Present and future applications of lipase, Biotechnol. Genet. Eng. Rev., 3,193 - 219 (1985).

[18] Mahanta N., Gupta A. and Khare S. K., Production of protease and lipase by solvent tolerant Pseudomonas aeruginosa PseA in solid-state fermentation using Jatropha curcas seed cake as substrate, Bioresour. Technol., 99, 1729-1735 (2008).

[19] Makhzoum A, Knapp J.Z, Owusu R.K., Factors affecting growth and extracellular lipase production by Pseudomonas fluorescens 2D, Food Microbial., 12,277290 (1995)

[22] Mohankumar C, Arumughan C, Kaleysa Raj R., Histological localization of oil palm fruit lipase, JAOCS, 67,665-669 (1990)

[23] Obradors N, Montesinos L, Valero F, Lafuente F.J, sola C., Effects of different fatty acids in lipase production by C. rucosa, Biotechnol. Lett., 15,357-360 (1993)

[24] Pandey A, Benjamin S, Soccol C R, Nigam P, Krierger $\mathrm{N}$ et al., The realm of microbial lipases in biotechnology, Biotechnol. Appl. Biochem., 29,119131 (1999)

[25] Rao P.V., Jayaraman K., Lakshmanan C.M., Production of lipase by Candida rugosa in solid state fermentation ,Medium optimization and effect of aeration, Proces. Biochem., 28, 391-395 (1993).

[26] Saima Rehman, Haq Nawaz Bhatti, Ijaz Ahmad Bhatti and Muhammad Asgher. Optimization of process parameters for enhanced production of lipase by Penicillium notatum using agricultural wastes, African J. of Biotechnol., 10, 19580-19589 (2011).

[27] Sarada sarkar, Sreekanth B., Shreya kant, Rintu Banarjee and Bhattacharya B.C., production and optimization of microbial lipase, Bioprocess and Biosys. Engg., 19, 29-32 (1998).

[28] Shu yang sun and Yan xu, Solid state fermentation for 'whole-cell synthetic lipase' production from Rhizopus chinensis and identification of the functional enzymes, Process Biochem., 43, 219-224 (2008).

[29] Silva W.O.B, Mitidieri S,Schrank A,Vainstein M.H., Production and extraction of an extracellular liapse from the entomopathogenic fungus Metarhizium anisopliae, Process Biochem., 40, 321-326 (2005)

[30] Tan T, Zhang M, Wang B, Ying C, Deng L., Screening of high lipase producing candida sp. and production of lipase by fermentation, Process Biochem., 39,459465 (2003)

[31] Tehreema Iftikar,Ikram-ul-haq, and mohammad mohsin javed. Optimization of culture conditions for the production of lipase by submerged culture of Rhizopus oligosporus Tuv-31, Pak .j. Bot., 35, 519-525 (2003).

[32] Thowlath Noora Parveen B. and Manikandaselvi S., Production of lipase enzyme by Aspergillus flavus using Groundnut waste, Int. J. of Pharm. Tech. Research, 3, 1299-1302, (2011).

[33] Vakhlu J, Kour A, Electron Yeast lipases: enzyme purification, biochemical properties and gene cloning, J., Biotechnol., 968,68-85 (2006). 